By CARL W. HINTZ

\title{
College and Research Libraries and the C.I.N.P.
}

$M r$. Hintz is librarian, University of Oregon, and member of the A.L.A. Committee on Implementation of the National Plans, representing the A.C.R.L.

$\mathrm{T}$ HE Executive Board of the American Library Association devoted considerable attention at its October 1947 meeting to various national plans of library groups and voted to establish a Committee on Implementation of the National Plans. This committee, made up of representatives of the various divisions of the Association, was somewhat hastily formed, and met for the first time at the Midwinter meeting. With this much of a preamble, we may raise three questions: What are the national plans? What is the C.I.N.P. supposed to do? Where do college and research libraries and librarians come into the picture?

In the first place, the plans are those set forth in the several publications in the $\mathrm{Li}$ brary Planning Series of the American Library Association's Committee on Postwar Planning, which have appeared to date; namely, Post-War Standards for Public Libraries (1943), Library Planning (1944), School Libraries for Today and Tomorrow (1945), College and University Libraries and Librarianship (1946), and A National Plan for Public Library Service (1948). The latter title marks the third and last stage of the Postwar Planning Committee's proposals for an over-all program for the American public library, and will perhaps be considered by many as the most significant of the series. Other volumes now in preparation will be concerned with library service to children and to adolescents. The titles in this series are evidence that the plans are not limited to one type of library, but are broad enough to include the kind of libraries whose staff members comprise the membership of the A.C.R.L.

In spite of the plural nature of the plans, however, the fact should be stressed that none of them is a detailed blueprint offered for blind acceptance. The concluding statement in A National Plan for Public Library Service, for instance, says:

This library plan should be recognized for what it is-a general guide to the organization of public library service throughout the United States. It is not a detailed prescription of precisely how service is to be provided in every state, every county and every city in the nation. It is proposed by the American Library Association for the thoughtful consideration of governmental agencies, library authorities and librarians everywhere. They may approve, amend, or adapt it to their special needs. The plan need not be followed in detail, but it is hoped that the principles on which it is founded will have general application.

Similarly, the preface to College and University Libraries and Librarianship states:

This study is not a plan in the blueprint sense. . . [rather, the practicing librarian] will, we hope, find here set forth at least some of the more fundamental principles which have governed, or should govern, the sound administration of college and university li- 
braries, and he will, we confidently believe, find a good deal of synthesis and analysis which will be useful in understanding present trends and determining future policies.

The plural nature of the plans and the variety of groups involved in their preparation and execution was fully recognized by the Executive Board of the American Library Association in its vote to authorize a special Committee on Implementation of the National Plans, and in the composition of the committee's membership. So far as the work of the committee is concerned, it is charged with promoting the utilization of the national plans looking toward the increase and improvement of all types of library service to a uniformly competent level throughout the nation. The committee proposes to do this by promoting and assisting the organization of state planning and implementation committees in every state and by urging the use of the national plans as common platforms on which citizens, trustees, and librarians can unite in the development of local library plans. The notable successes achieved by planning groups in some states during past years indicates that this offers the best approach to the problem of implementation, particularly if a wide variety of occupational, social, and official groups are represented. A second essential is a sound publicity campaign which, due to the present lack of financial backing for the committee, must be conducted largely at the local level.

Obviously, college and research libraries, beyond being represented on the committee, have a great deal to contribute to such a movement, particularly at the advisory and leadership level. In fact, there are sound arguments reinforcing the idealistic one of professional solidarity, why this group should be particularly active.

The old truism that "no man is an island unto himself" still holds. At first sight, there may appear to be but little community of interest between the very small public library, for instance, and the large university library. The fact remains, however, that many people gain their only knowledge of library service and librarians, too, from their local institutions. Is it too much to suggest that this affects the prestige of the profession as a whole, and consequently may have repercussions on recruiting? Probably every reader of this paper has had the experience of seeing a somewhat blank and puzzled expression come over his questioner's face upon being told "I am a librarian." Second, college and university librarians frequently complain about the lack of library knowledge on the part of their student bodies, particularly at the freshman level. This is to be expected, as long as numbers of students come from areas with substandard or no library service at all. Better school and public libraries are one means of remedying this deficiency in the precollege student's education.

This nationwide movement to implement the national plans is designed to consolidate the efforts of citizens and librarians everywhere into a concerted drive to make the general public conscious of the library's role in today's and tomorrow's world. What are its implications for college and research libraries? A library conscious public will make for a library conscious government with all that this means in the way of funds and support for better librarianship at all levels. The end result is one in which we may all take a justifiable pride and interest, namely, an impetus to scholarship on a nationwide scale. The teaching potential of the library is great. A volume placed in a youngster's hand in a small public library today may provide the initial introduction to books of tomorrow's research library patron. Who can deny that we all have a stake in the national plans? 